\title{
Glucocorticoids suppress macrophage migration inhibitory factor (MIF) expression in a cell-type-specific manner
}

\author{
Z Alourfi ${ }^{1,2,3}$, R P Donn ${ }^{1,3}$, A Stevens ${ }^{1,2}$, A Berry ${ }^{2,3}$, A McMaster $^{1-3}$ and D W Ray ${ }^{2,3}$ \\ ${ }^{1}$ ARC Epidemiology Unit, ${ }^{2}$ Endocrine Sciences Research Group, and ${ }^{3}$ Centre for Molecular Medicine, Faculty of Medicine, University of Manchester, Manchester M13 9PT, UK \\ (Requests for offprints should be addressed to D W Ray, Endocrine Sciences Research Group, Stopford Building, University of Manchester, Manchester M13 9PT, UK; \\ Email David.W.Ray@man.ac.uk)
}

\begin{abstract}
MIF is a potent proinflammatory cytokine involved in inflammatory arthritis. Glucocorticoids (GC) have been reported to induce secretion of MIF in rodent cells, and as MIF counteracts the anti-inflammatory effects of GC, this has implications for human inflammatory disease. Transient transfection studies showed that the MIF promoter was repressed by dexamethasone (Dex) (10 nM) in CEM C7A cells, with up to 50\% suppression by $100 \mathrm{nM}$. However, there was no regulation of the promoter by GC in A549 cells. We also found that subnanomolar concentrations of Dex suppressed MIF secretion, measured by ELISA, by $80 \%$ in both human T lymphoblasts (CEM C7A) and human lung epithelial cells (A549). Endogenous MIF mRNA was also repressed by GC in CEM C7A cells, measured both by Northern blot and quantitative RT-PCR assays, but there was no such regulation in A549 cells. This suggests that GC affects translation rather than transcription of MIF in A549 cells. These results contradict earlier results with the rat cell line RAW 264.7. Therefore, we analysed MIF secretion from RAW 264.7 cells but found no GC effect on secretion. Understanding how GC regulates MIF in a cell-type-dependent manner may give insights into GC-refractory human inflammatory diseases.
\end{abstract}

Journal of Molecular Endocrinology (2005) 34, 583-595

\section{Introduction}

Macrophage migration inhibitory factor (MIF) is a potent proinflammatory cytokine originally identified by its action on macrophages (Bloom \& Bennett 1966, David 1966). Subsequently, it was cloned and found to be widely expressed in tissues such as the pituitary, macrophage, lymphocyte and lung (Paralkar \& Wistow 1994). MIF was found to oppose the anti-inflammatory actions of glucocorticoids (GC) on proinflammatory cytokine expression (Calandra et al. 1995).

MIF regulation by GC is more complex; however, very low concentrations $\left(10^{-14} \mathrm{M}\right.$ dexamethasone (Dex)) have been shown to stimulate MIF secretion (Calandra et al. 1995, Petrovsky et al. 2003). This induction of MIF secretion was not accompanied by changes in MIF gene expression, and post-translational mechanisms were proposed (Fingerle-Rowson et al. 2003).

Elevated concentrations of MIF have been found in the peripheral blood of patients with inflammatory diseases, and MIF immunoreactivity has also been described within sites of inflammation including those of inflammatory arthritis, colitis and psoriatic skin lesions (reviewed by (Nishihira 1998, Lue et al. 2002). A direct role for MIF in the aetiology of the inflammatory process was supported by both immunoneutralisation studies (Mikulowska et al. 1997, Leech et al. 1998, Santos et al. 2001) and analysis of MIF-null mice (Bozza et al. 1999, Leech et al. 2003).

Studies of MIF gene polymorphisms in human adult and childhood onset arthritis have confirmed MIF as an important susceptibility locus (Baugh et al. 2002, Donn et al. 2002, Barton et al. 2003, De Benedetti et al. 2003). A specific MIF haplotype of a polymorphic tetranucleotide repeat and promoter single nucleotide polymorphism (SNP) [CATT 7 -MIF-173*G] confers increased risk of both adult rheumatoid arthritis (Barton et al. 2003) and juvenile idiopathic arthritis (Donn et al. 2001). Further analysis of the polymorphic MIF promoter showed cell-type specific differences in transcription and increased promoter activity of this 'risk' haplotype in CEM C7A cells (Donn et al. 2004).

GCis are the most potent anti-inflammatory agents known. They act through the glucocorticoid receptor (GR), which undergoes nuclear translocation on ligand binding and binds to DNA. Many of the antiinflammatory actions of GC are mediated by tethering of the GR to DNA-bound AP-1 and NFкB, and subsequently recruitment of repressor proteins, including GRIP1 (Rogatsky et al. 2002). However, there are likely to be differences in the mechanism depending on the DNA sequence of the AP-1 or NFKB response elements and the presence of other flanking transcription factor-binding sites (Diamond et al. 1990, Baniahmad et al. 1991, Muller et al. 1991, Huynh et al. 2002, 
Rogatsky et al. 2003). Analysis of the MIF gene sequence revealed $\mathrm{AP}-1$ and $\mathrm{NF \kappa B}$ responsive elements but no classical GG response elements (Baugh et al. 2002).

MIF is an important proinflammatory cytokine. Reports have suggested that its secretion, and possibly expression, are positively regulated by GG (Petrovsky et al. 2003). In addition, MIF gene polymorphisms are positively associated with increased risk of inflammatory arthritis (Donn et al. 2002, 2004, Barton et al. 2003). We therefore have studied GC regulation of the human MIF gene.

\section{Materials and methods}

\section{Cell culture and regulation of MIF promoter}

GEM C7A cells (human T lymphoblast), A549 cells (human lung epithelial) and RAW264.7 (murine macrophage-like) were obtained from ECGAC. CEM C7A were cultured in RPMI1640 (Gibco BRL, Paisley, UK), and both RAW264.7 cells and A549 cells were routinely cultured in DMEM with glutamax (Gibco BRL) with fetal bovine serum (FBS) (Perbio, Tattenhall, Cheshire, UK, HyClone-Catalog no. SH30068). This batch of FBS was found to contain less than $9 \mathrm{nM}$ cortisol as measured by RIA, as previously reported (Stevens et al. 2004), giving a final calculated concentration in the cell-culture medium of less than $1 \mathrm{nM}$. The FBS was not heat inactivated (Anonymous 1996). Cells were incubated at $5 \% \mathrm{CO}_{2}$ and $37^{\circ} \mathrm{C}$ with or without varying concentrations of dexamethasone (Sigma, Poole, UK) for $24 \mathrm{~h}$. Studies were performed in both the absence and presence of FBS (1 and 10\%).

\section{MIF gene promoter studies}

The MIF reporter plasmids have been described previously (Donn et al. 2004). Briefly, MIF-173*G/C plasmids were made by the amplification of nucleotides -775 to +85 (Genbank accession no. L19686 (EMBL ID:HSMIF)) and inserted into pGL3-luc as previously described (Donn et al. 2002). Individuals carrying five, six and seven repeat alleles were identified, and genomic DNA was amplified between MIF -1075 and MIF -600 (Genbank accession no. L19686 (EMBL ID:HSMIF)). These inserts were ligated upstream of the MIF-luc sequences described above. This resulted in six new plasmids one for each repeat allele $(5-7)$ on both a MIF-C and MIF-G background. These plasmids were named $\mathrm{CATT}_{5-7}-\mathrm{MIF}-173 * \mathrm{G} / \mathrm{C}$.

SV40-luc, containing the SV40 promoter is the same pGL3-luc plasmid, was purchased from Promega. The glucocorticoid response MMTV-luc reporter gene was previously described (Soden et al. 2002, Stevens et al. 2003).

\section{Transient transfections of CEM C7A cells and A549 cells}

CEM C7A cells were cultured in medium supplemented with $10 \%$ FBS. Cells were suspended at $10^{7}$ cells per ml, and $0.8 \mathrm{ml}$ were added to a $4 \mathrm{~mm}$ path-length electroporation cuvette (Bio-Rad, Hercules, CA, USA). An amount of $10 \mu \mathrm{g}$ MIF plasmid DNA was added, and the cells were electroporated at $260 \mathrm{~V}$ and $1050 \mu \mathrm{F}$ in an 'Easyjectl' electroporator (Eurogentech, Liege, Belgium).

A549 cells were cultured in medium supplemented with $10 \%$ FBS. Cells $\left(10^{5}\right)$ were transfected with Lipofectamine 2000, according to the manufacturer's instructions (Gibco BRL).

After transfection, both cell lines were divided into control and treatment groups with $10^{-7} \mathrm{M}$ phorbol 12-myristate acetate (PMA), or Dex $\left(10^{-12}\right.$ to $\left.10^{-6} \mathrm{M}\right)$ in the presence or absence of Mifepristone (RU486) (Affinity Bioreagents, Golden, CO, USA). After that, cells were incubated for $20 \mathrm{~h}$ at $37{ }^{\circ} \mathrm{C}$ and $5 \% \mathrm{CO}_{2}$. In another set of transfections, cells were transfected and incubated overnight at $37^{\circ} \mathrm{C}$ and $5 \% \mathrm{CO}_{2}$. Then they were incubated for $6 \mathrm{~h}$ with $250 \mu \mathrm{M} \mathrm{cpt}$ cAMP (Sigma). Luciferase activity in cell lysates was detected, as previously described (Ray et al. 1999), using a tube luminometer (LB 9501; Berthold, Wildbad, Germany).

All transfections were performed in triplicate on at least two occasions. Transfection efficiency was determined in a series of experiments using cotransfected CMV-Renilla (Promega). The mean difference in Renilla luciferase activity within an experiment was $7 \%$; therefore, no specific correction was made (Boutillier et al. 1991).

\section{Measurement of MIF protein by ELISA}

MIF protein was measured using DuoSet ELISA Development System human MIF (R\&D Systems, Minneapolis, MN, USA; catalog no. DY289) with a monoclonal mouse anti-human MIF antibody to MIF for coating and a biotinylated goat antibody to MIF for detection. The assay was performed in accordance with the manufacturer's instructions together with modifications made subsequent to a series of experiments designed to optimise MIF recovery and the assay's specificity and sensitivity. Recombinant human MIF (R\&D Systems, catalog no. 289-MF) was used as standard and for optimisation.

The apparent recovery of $4 \mathrm{ng} / \mathrm{ml}$ recombinant human MIF spiked in cell-culture medium supplemented with $1 \%$ or $10 \%$ FBS was 25 and $88 \%$ respectively. All samples were assayed in the same assay, at the same diluent (1:4 dilution). The detection limit of the assay was $64 \mathrm{pg} / \mathrm{ml}$. 


\section{Measurement of MIF mRNA}

\section{Northern blotting}

A 354 bp fragment of MIF cDNA was amplified for use as a probe, using the following primers and conditions: forward primer $5^{\prime}$ ccatcatgccgatgttca $3^{\prime}$ and reverse primer $5^{\prime}$ cttaggcgaaggtggagttg $3^{\prime}$, and a target of $500 \mathrm{ng}$ cDNA from CEMC7 cells was amplified with the ABgene PCR Mastermix kit (ABgene, Epsom, UK), according to the manufacturer's instructions, using a 9700 PGR machine (Perkin Elmer, Warrington, UK) with the following cycling conditions: $95^{\circ} \mathrm{C}$ for $5 \mathrm{~min}$ and 30 cycles of $95{ }^{\circ} \mathrm{C}$ for $45 \mathrm{~s}, 55^{\circ} \mathrm{C}$ for $45 \mathrm{~s}$ and $72{ }^{\circ} \mathrm{C}$ for $45 \mathrm{~s}$, with a final extension step at $72{ }^{\circ} \mathrm{C}$ for $5 \mathrm{~min}$. The PCR products were separated by electrophoresis, and the $354 \mathrm{bp}$ fragment of MIF cDNA PCR was purified from the gel with a gel purification kit (Qiagen) and was biotin labelled with the BrightStar PsoralenBiotin non-isotopic labelling kit (Ambion, Huntingdon, UK).

A549 and CEMC7 cells were seeded at $1.5 \times 10^{6}$ in $10 \mathrm{~cm}$ dishes, and the next day Dex $(100 \mathrm{nM}$ final concentration) was added (to three plates of each cell line) and the cells were incubated for a further $24 \mathrm{~h}$. Total RNA was purified from the cells with the RNAeasy kit (Qiagen), according to the manufacturer's instructions.

Total RNA from the cells was prepared for Northern blotting with the NorthernMax-Gly kit (Ambion); briefly, $10 \mu \mathrm{g}$ of total RNA from each sample was mixed with glyoxal loading dye and incubated at $50{ }^{\circ} \mathrm{C}$ for $30 \mathrm{~min}$, the samples were run out on a $1 \%$ agarose gel and the integrity of the RNA was checked by examination under u.v. light. The RNA was then transferred to positively charged nylon membrane (BrightStar-Plus; Ambion) with NorthernMax transfer buffer (Ambion) and cross-linked using a u.v. cross-linker (SpectrolinkerXL1000; Spectronics Corporation, Westbury, NY, USA), according to the manufacturer's instructions.

The membrane was then prehybridised for $1 \mathrm{~h}$ in ULTRAhyb buffer (Ambion) at $42{ }^{\circ} \mathrm{C}$. The biotinylated MIF probe was added to the prehybridisation buffer to a final concentration of $1.0 \mathrm{pM}$, and the membrane was left to hybridise overnight. One low-stringency wash was performed at room temperature followed by two high-stringency washes at $42{ }^{\circ} \mathrm{C}$. Chemiluminescent detection was performed with the BrightStar kit (Ambion).

\section{Quantitative RT-PCR}

Total cell RNA was harvested with TRIZOL (Gibco BRL) and treated with RNase-free DNase (Promega, Southampton, UK), and then cDNA was synthesised with the Reverse-iT First Strand Synthesis Kit (ABgene, $\mathrm{AB}-0789 / \mathrm{b})$.
Real-time PCR was carried out with TaqMan-ABI PRISM 7700. To allow for relative quantitation, a serial two-fold dilution of a total cDNA preparation from a control cell line was used to construct a standard curve, starting with $5 \mathrm{ng} / \mathrm{ml}$. All primers were supplied by Applied Biosystems (Foster City, CA, USA). The MIF detection primer was labelled with the reporter dye FAM, and endogenous controls were labelled with VIG (GAPDH and 18S were used for murine cells, and GAPDH and $\beta$-actin for human cells).

Delta Delta CT $(\Delta \Delta \mathrm{CT})$ comparisons were made following the methods of User Bulletin no. 2, ABI PRISM 7700 Sequence Detection System; Applied Biosystems, 11 December 1997 (updated October 2001).

\section{Statistical analysis}

All statistical analyses were performed by ANOVA and the Bonferroni $t$-test, or independent sample $t$-test (SPSS, Version $10 \cdot 1$, Chicago, IL, USA). All data are expressed as mean \pm S.D. Differences at $P<0 \cdot 05$ were considered significant.

\section{Results}

\section{MIF promoter analysis in CEM C7A cells and A549 cells}

We have previously defined cell-type specific differences in basal promoter activity dependent on the carriage of two sites of genetic variation $\mathrm{CATT}_{(5-7)}-\mathrm{MIF}-173 * \mathrm{G} / \mathrm{C}$ in two human cell lines, CEM C7A and A549 (Donn et al. 2004); and so a series of MIF luciferase reporter constructs was examined, representing all the possible combinations of alleles, and regulation by Dex measured by transient transfection.

In CEM C7A cells there was clear evidence of Dex dose-dependent inhibition of promoter activity. There was detectable repression by $10^{-8} \mathrm{M}$ Dex and $50 \%$ inhibition by $10^{-6} \mathrm{M}$ Dex. We were unable to find differences between the different MIF promoter haplotypes examined. Importantly, there was no suggestion of an induction in MIF promoter activity at low concentrations of Dex (Fig. 1a). RU486, a GC antagonist, abolished Dex suppression of MIF promoter activity (Fig. 2) and the natural glucocorticoid, hydrocortisone, was also effective at inhibiting MIF promoter activity.

There was no Dex regulation of a transiently transfected plasmid identical to MIF-luc, but with the MIF promoter substituted for an SV40 promoter (data not shown), but dexamethasone did effectively induce the MMTV promoter in CEM C7A cells transfected and treated in the same way (Fig. 2).

In contrast to the inhibition of MIF promoter function seen in CEM C7A cells, there was no inhibition seen in A549 cells (Fig. 1b).

Journal of Molecular Endocrinology (2005) 34, 583-595 

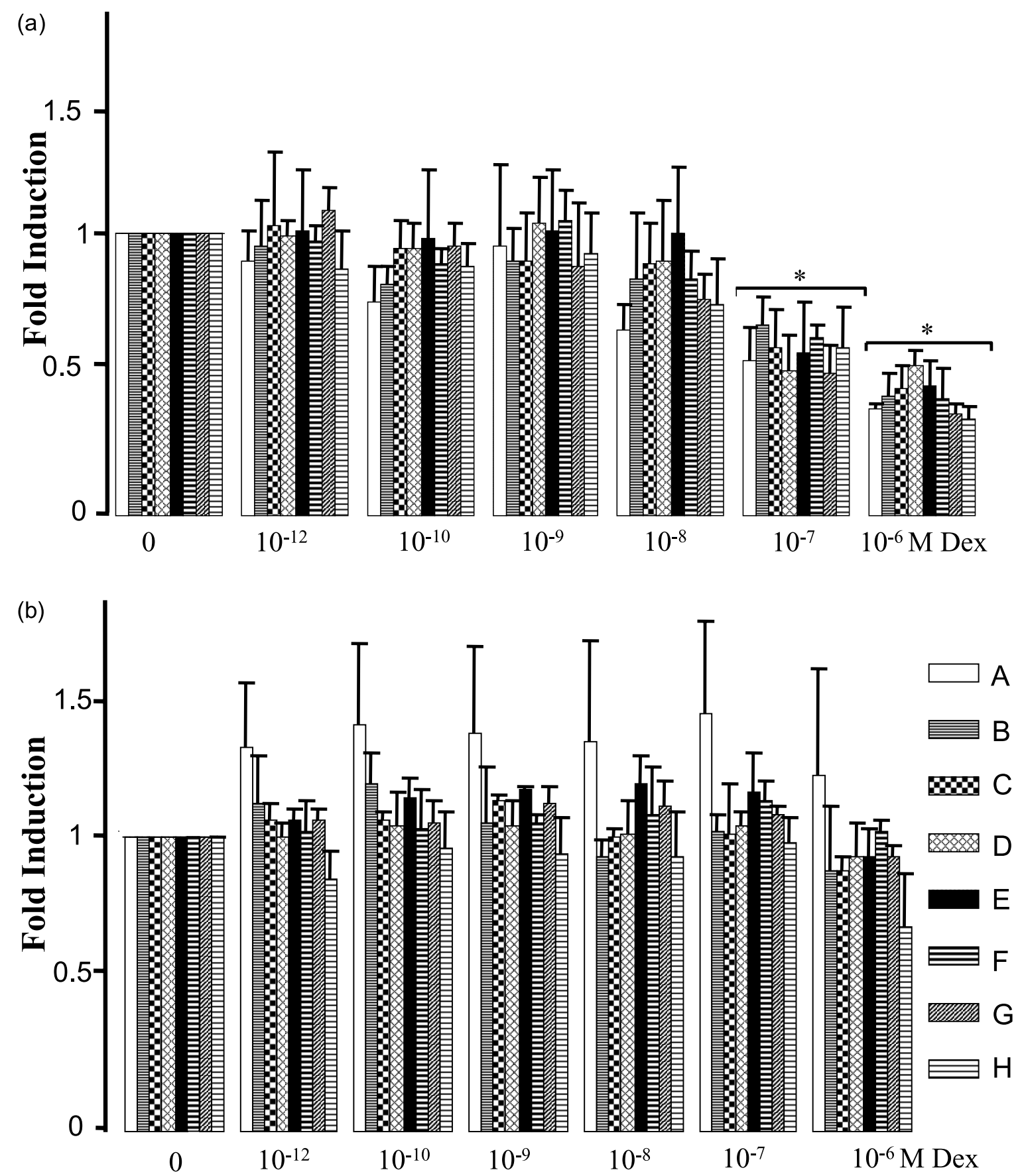

Figure 1 Regulation of wild-type, and polymorphic MIF promoter haplotypes in (a) CEM C7A and (b) A549 cells. Cells were transfected with $\mathrm{CATT}_{(5-7)}-\mathrm{MIF}-173^{\star} \mathrm{G} / \mathrm{C}$-Luc reporter constructs, and then divided into treatment and control cultures. Cells were incubated with the indicated concentrations of dexamethasone (Dex) for $20 \mathrm{~h}$ before harvest. Cell lysates were analysed for luciferase content and results compared with the vehicle control for each cell line. A representative experiment, performed in triplicate, is presented. The experiment was performed on two occasions with similar results. Statistical analysis was by ANOVA and Bonferroni $t$-test. ${ }^{*} P<0.05$ compared with vehicle control.

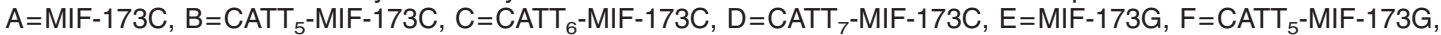
$\mathrm{G}=\mathrm{CATT}_{6}-\mathrm{MIF}-173 \mathrm{G}, \mathrm{H}=\mathrm{CATT}_{7}-\mathrm{MIF}-173 \mathrm{G}$. 

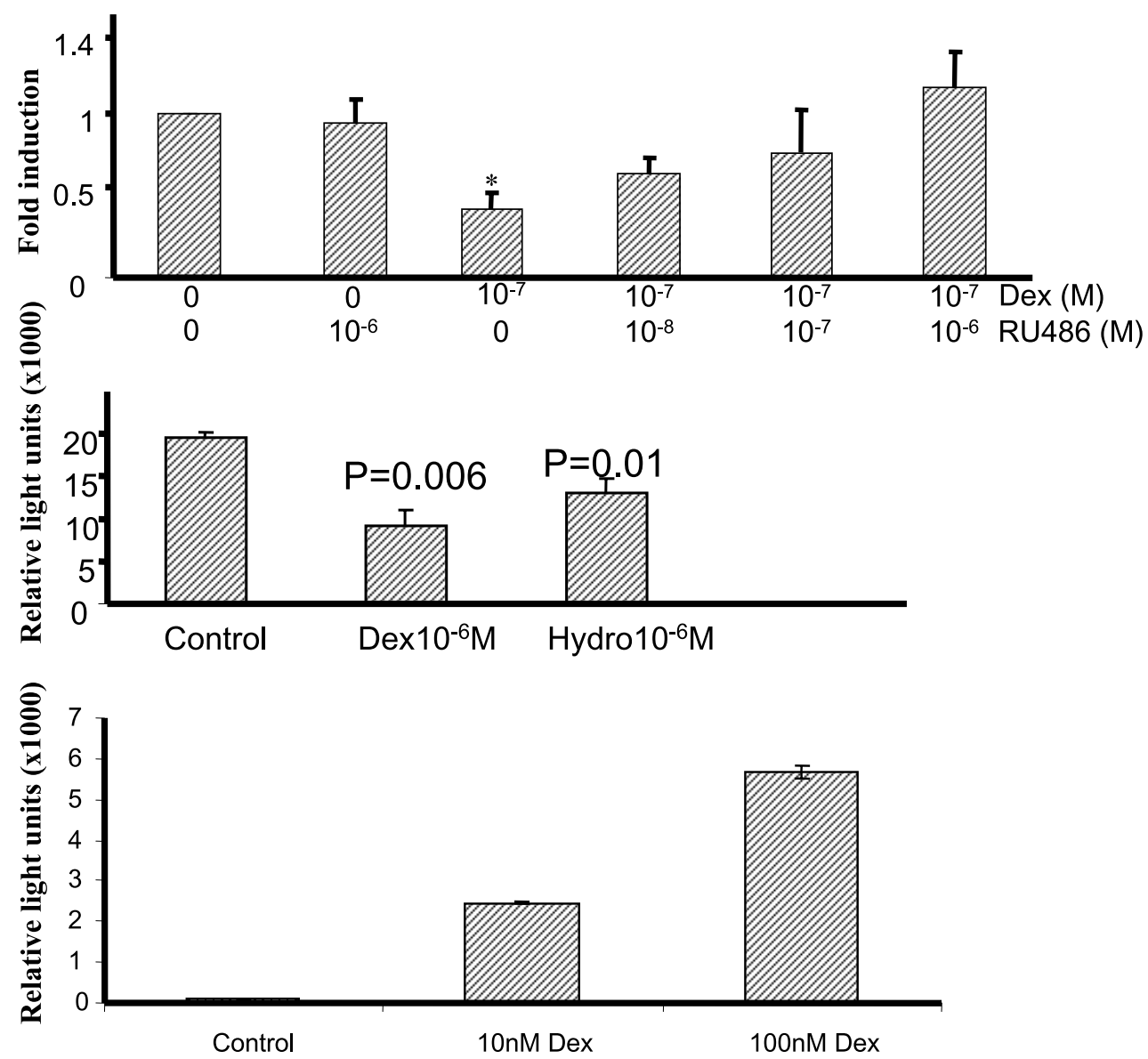

Figure 2 Glucocorticoid regulation of the MIF promoter depends on the glucocorticoid receptor.

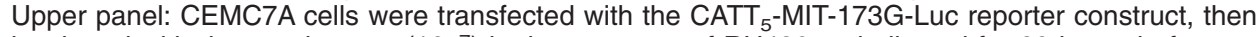
incubated with dexamethasone $\left(10^{-7}\right)$ in the presence of RU486 as indicated for 20 hours before harvest. Cell lysates were analysed for luciferase content. *Indicates $P<0.05$ compared to vehicle control. Middle panel: CEM C7A cells were transfected as above, and incubated with dexamethasone, or hydrocortisone (Hydro) for 20 hours, before harvest and anlaysis as above. Exact significance is shown, compared to control. Lower panel: CEM C7A cells were transfected as above, but with the MMTV-luc glucocorticoid induced reporter gene, and incubated with dexamethasone, at the indicated concentrations for 20 hours, before harvest and analysis as above.

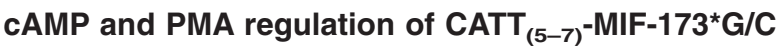 gene promoter activity in CEM C7A cells}

CEM C7A cells were transfected with $\mathrm{CATT}_{(5-7)}$-MIF$173^{*} \mathrm{G} / \mathrm{C}$ and subsequently treated with cAMP or PMA. There was no induction of the MIF reporter genes in the presence of cpt cAMP (Fig. 3a). However, there was significant induction of a $-1149 \mathrm{G}$ prolactin plasmid (three-fold increase) when transfected into GEM C7A cells and treated with $250 \mu \mathrm{M}$ cpt cAMP (Fig. 3b). There was a significant induction of all constructs seen with phorbol ester (PMA) (Fig. 4).

\section{GC regulation of MIF secretion}

As earlier reports had examined MIF release under conditions of serum deprivation (Calandra et al. 1995), we examined MIF secretion by CEM G7A cells in either serum-free medium, or with $1 \%$ FBS in comparison with $10 \%$ FBS. There was no regulation of MIF release by $10^{-6} \mathrm{M}$ Dex under either serum-deprivation conditions (Fig. 5a and b), but there was $80 \%$ suppression by Dex with $10 \%$ FBS medium (Fig. 5c).

As cell-type-specific differences were seen in GC regulation of MIF promoter gene activity, we attempted to find out if there are also differences in GC regulation of MIF protein secretion by the same cell lines, CEM C7A and A549. Cells were cultured with medium supplemented with 10\% FBS and incubated with increasing concentrations of Dex for $24 \mathrm{~h}$, conditioned medium was assayed for MIF by ELISA. These studies identified significant suppression of MIF release by $10^{-10}$ M Dex in CEM C7A cells (Fig. 6a). There was no 
(a)

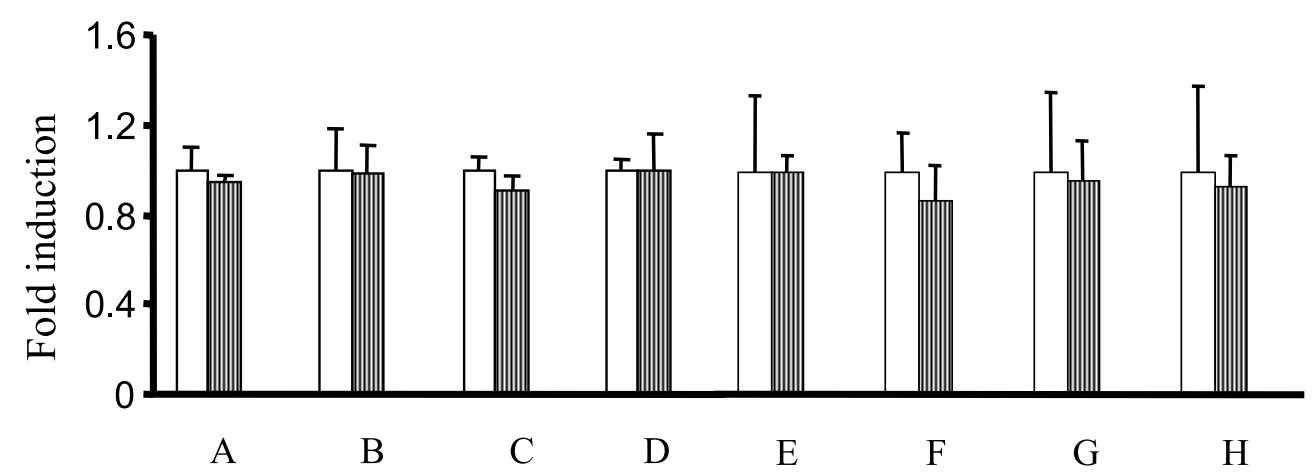

(b)

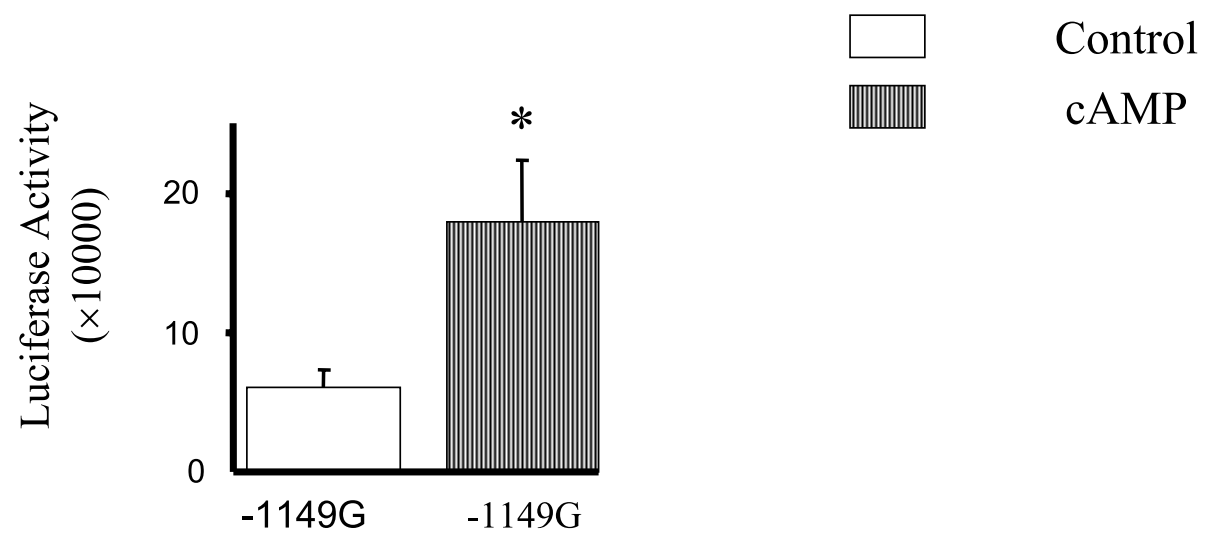

Figure 3 Regulation of wild-type, and polymorphic MIF promoter haplotypes CATT ${ }_{(5-7)}-\mathrm{MIF}-173^{*} \mathrm{G} / \mathrm{C}$ by cAMP. CEM C7A cells were transfected with (a) CATT $_{5-7}-M_{I F-173}{ }^{*} \mathrm{G} / \mathrm{C}$-Luc or (b) prolactin-1149 G reporter constructs and incubated overnight at $5 \% \mathrm{CO}_{2}$ and $37^{\circ} \mathrm{C}$. Then they were incubated again for $6 \mathrm{~h}$ with or without $250 \mu \mathrm{M}$ cpt cAMP before harvest. Cell lysates were analysed for luciferase content. A representative experiment, performed in triplicate, is presented. Statistical analysis was by ANOVA, and Bonferroni $t$-test. ${ }^{*} P<0.05$ compared with vehicle control. $A=M I F-173 C, B=C T_{T}-M I F-173 C$, $\mathrm{C}=\mathrm{CATT}_{6}-\mathrm{MIF}-173 \mathrm{C}, \mathrm{D}=\mathrm{CATT}_{7}-\mathrm{MIF}-173 \mathrm{C}, \mathrm{E}=\mathrm{MIF}-173 \mathrm{G}, \mathrm{F}=\mathrm{CATT}_{5}-\mathrm{MIF}-173 \mathrm{G}, \mathrm{G}=\mathrm{CATT}_{6}-\mathrm{MIF}^{-173 G}$, $\mathrm{H}=\mathrm{CATT}_{7}-\mathrm{MIF}-173 \mathrm{G}$.

induction of MIF secretion seen at lower concentrations of Dex. Surprisingly, in A549 cells, highly significant repression was seen (at $10^{-12} \mathrm{M}$ Dex), with MIF secretion reduced by $90 \%$ at higher concentrations of Dex (Fig. 6b).

\section{GC regulation of MIF mRNA}

Our experiments showed that there is a cell-type-specific difference in Dex regulation of MIF reporter gene activity in CEM C7A and A549 cells, but not in Dex regulation of MIF protein secretion. MIF mRNA was measured in the two index cell lines by Northern blot analysis. There was marked suppression of MIF mRNA by Dex in CEM C7A cells, and, surprisingly, no effect in A549 cells (Fig. 7). To future explore this cell-typespecific difference in the GG responsiveness of MIF
mRNA levels, a quantitative RT-PCR approach was used. This identified $42 \%$ suppression of MIF mRNA in CEM C7A cells $(P=0.01)$, but although there was suppression seen in A549 cells (Fig. 8), this did not reach significance $(P=0 \cdot 13)$. This accords with the results of regulation seen in MIF gene promoter activity in both cell lines.

\section{GC regulation of MIF mRNA and secretion in RAW264.7 cells}

RAW264.7 cells were cultured in DMEM $+1 \%$ heatinactivated FBS with or without Dex for $24 \mathrm{~h}$ (the same conditions used in the previous report (Calandra et al. 1995)). Conditioned medium was assayed for MIF by ELISA after $24 \mathrm{~h}$ incubation. There was no regulation by Dex, and furthermore there was no regulation seen 


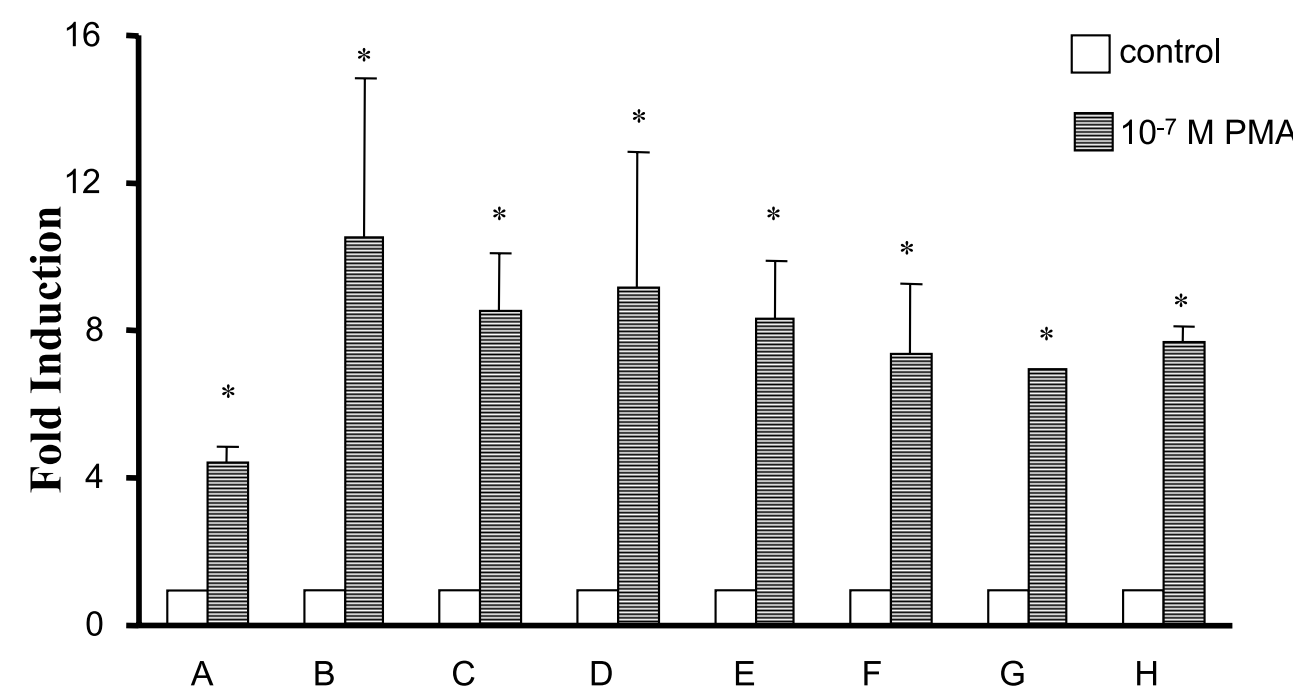

Figure 4 Phorbol ester (PMA) regulation of wild-type, and polymorphic MIF promoter haplotypes

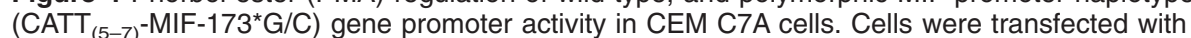
$\mathrm{CATT}_{5-7}-\mathrm{MIF}-173^{*} \mathrm{G} / \mathrm{C}$-Luc reporter constructs, and then they were incubated with or without $10^{-7} \mathrm{M}$ PMA for $20 \mathrm{~h}$ before harvest. Cell lysates were analysed for luciferase content. A representative experiment, performed in triplicate, is presented. Statistical analysis was by ANOVA and Bonferroni $t$-test. ${ }^{*} P<0.05$ compared with vehicle control. $A=M I F-173 C, B=\mathrm{CATT}_{5}-\mathrm{MIF}-173 \mathrm{C}$,

$\mathrm{C}=\mathrm{CATT}_{6}-\mathrm{MIF}-173 \mathrm{C}, \mathrm{D}=\mathrm{CATT}_{7}-\mathrm{MIF}-173 \mathrm{C}, \mathrm{E}=\mathrm{MIF}-173 \mathrm{G}, \mathrm{F}=\mathrm{CATT}_{5} \mathrm{MIF}-173 \mathrm{G}, \mathrm{G}=\mathrm{CATT}_{6}-\mathrm{MIF}-173 \mathrm{G}$, $\mathrm{H}=\mathrm{CATT}_{7}-\mathrm{MIF}-173 \mathrm{G}$.

with either $10 \%$ heat inactivated FBS, or $10 \%$ charcoal stripped serum (Fig. 9), and also there was no effect seen with $10 \%$ FBS (data not shown).
In addition RAW264.7 cells were cultured in DMEM + 1\% FBS with or without Dex for 3, 12 and $24 \mathrm{~h}$, and again we saw no regulation of MIF secretion
a
b
C

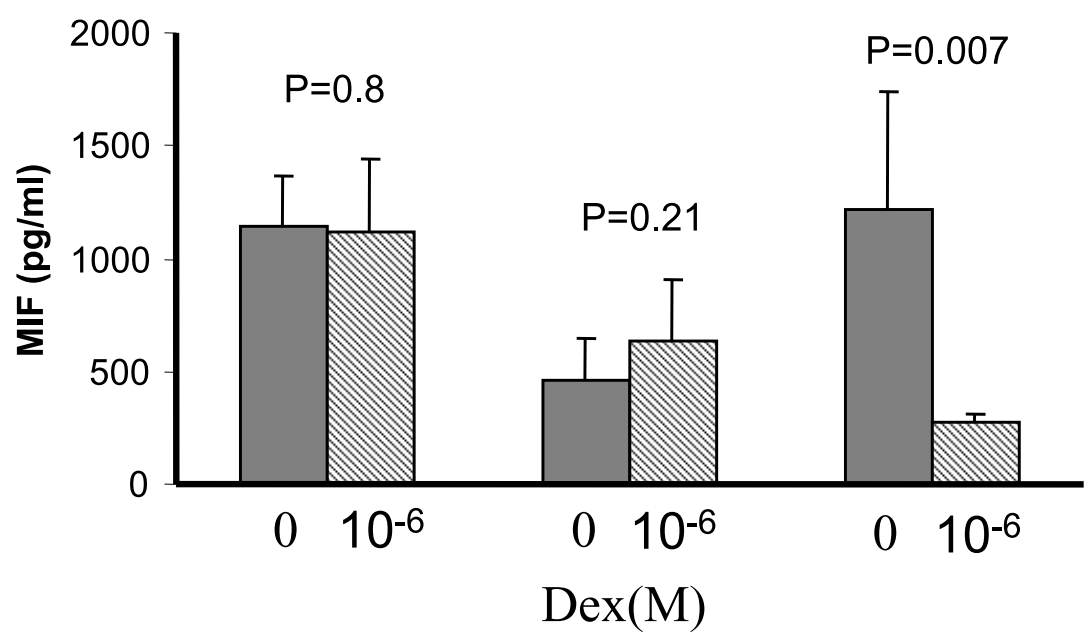

Figure 5 Glucocorticoid regulation of MIF secretion and influence of serum concentration. CEM C7A cells were cultured in (a) serum-free medium, (b) $1 \%$ FBS or (c) $10 \%$ FBS. Cells were incubated with vehicle, or with dexamethasone (Dex) as indicated for $24 \mathrm{~h}$ before recovery of conditioned medium. The MIF concentration was determined by ELISA. Representative experiments performed in sextuplicate are presented. Exact significance compared to the Dex free control is shown by independent sample $t$-test. 


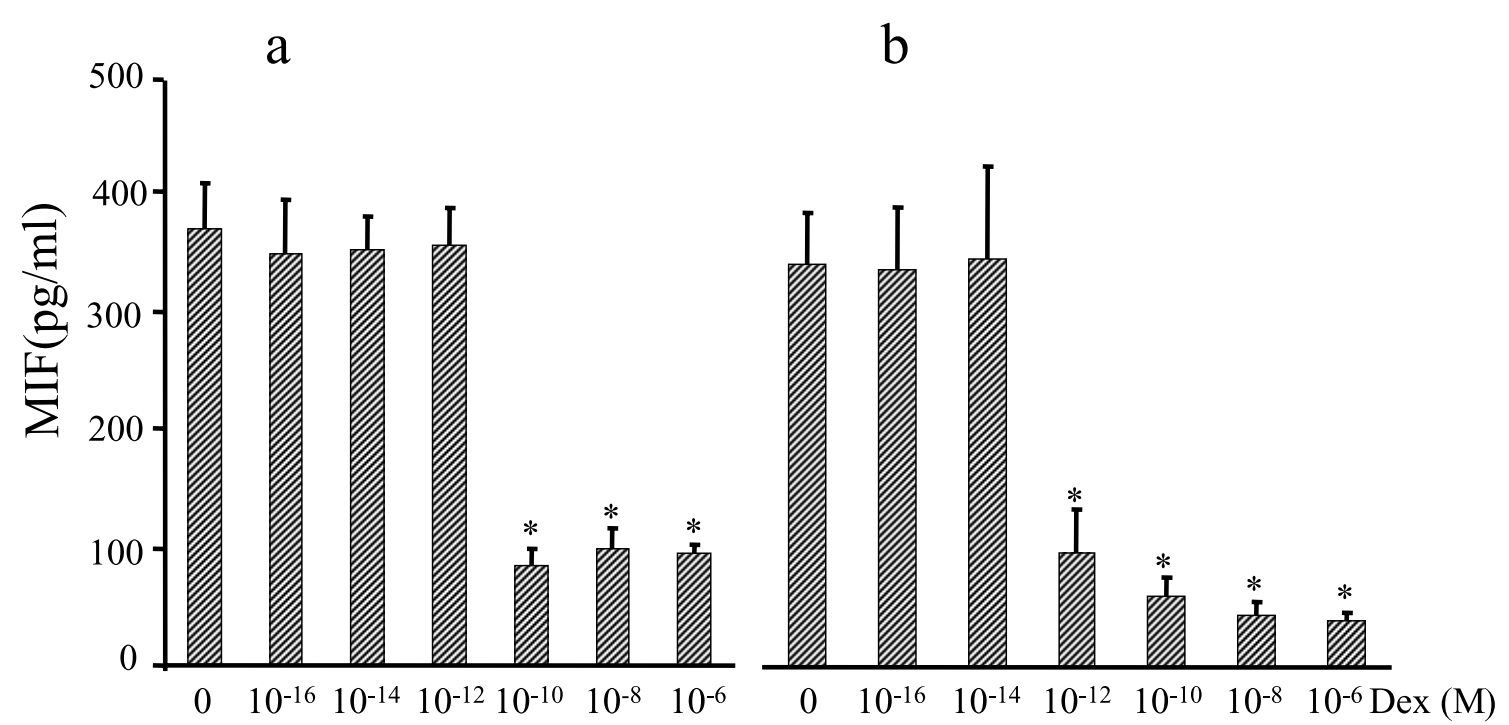

Figure 6 Regulation of MIF secretion by glucocorticoid. CEM C7A (a) and A549 (b) cells were cultured as described with medium supplemented with $10 \%$ FBS, and incubated with dexamethasone (Dex). Conditioned medium was recovered and MIF content determined by ELISA. Representative experiments, performed in triplicate, are presented; mean and standard deviation. Experiments were performed on at least three separate occasions with similar results. Statistical analysis was by ANOVA and Bonferroni $t$-test. ${ }^{*} P<0.001$.

(data not shown). These cells were harvested fro RNA extraction, and MIF transcripts were measured by qRT-PCR. There was no glucocorticoid effect on MIF mRNA (Fig. 10).

\section{Discussion}

MIF is an important pro-inflammatory cytokine found to be expressed at sites of inflammation and also to be
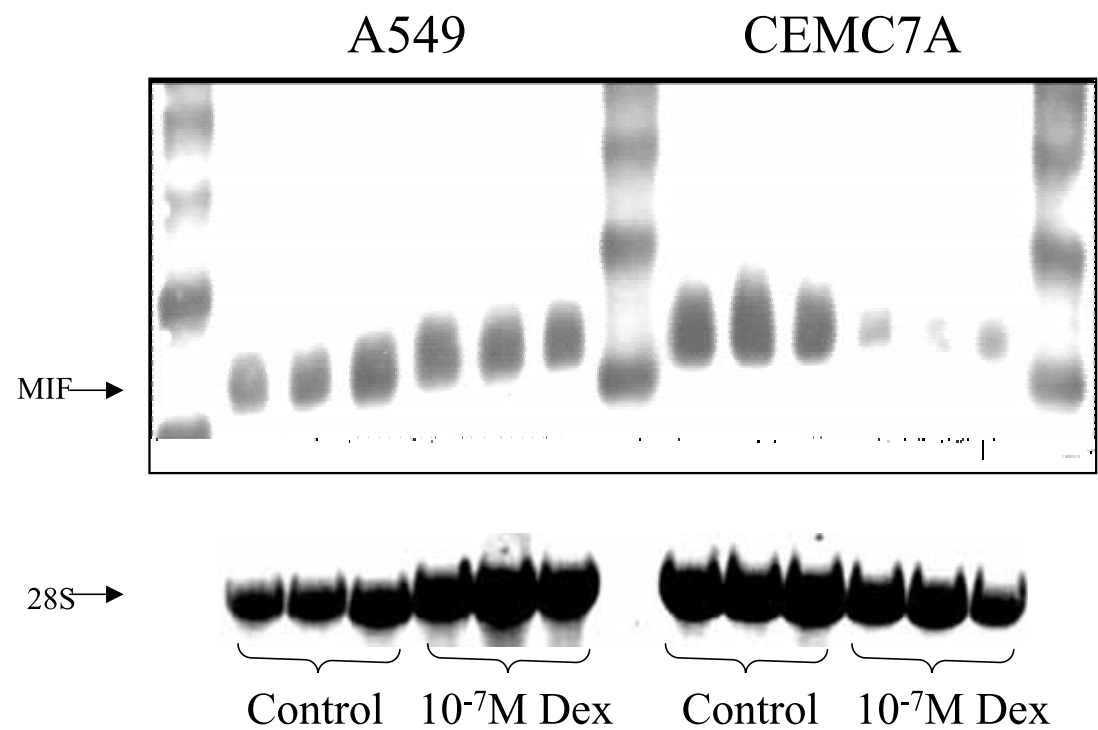

Figure 7 Glucocorticoid regulation of MIF mRNA abundance in CEM C7A and A549 cells. Cells were incubated overnight in medium with $10 \%$ FBS with vehicle or $10^{-7} \mathrm{M}$ dexamethasone (Dex) in triplicate. Total cell RNA was harvested and analysed by Northern blotting for MIF expression. Equal loading is indicated by the $28 \mathrm{~S}$ ribosomal RNA band. 


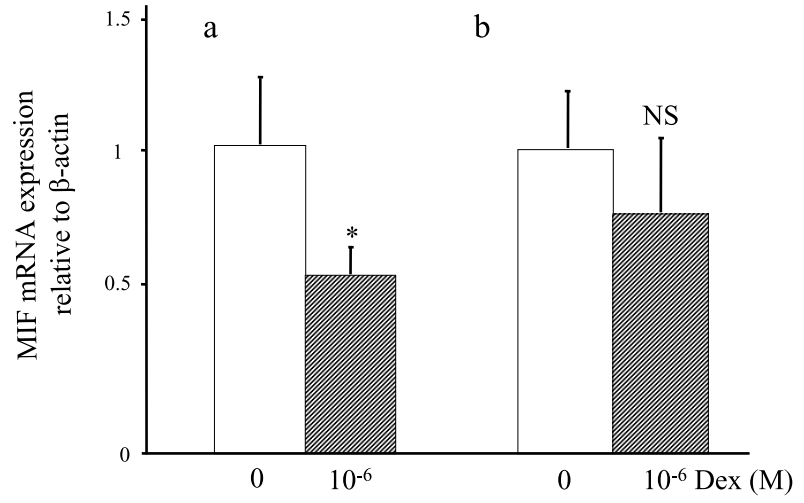

Figure 8 Glucocorticoid regulation of MIF mRNA in (a) CEM C7A and (b) A549 cells. Cells were cultured in medium with $10 \%$ FBS and with either vehicle or dexamethasone (Dex) as indicated and incubated for $24 \mathrm{~h}$. Total cell RNA was harvested, and CDNA was generated and analysed by quantitative RT-PCR for MIF expression relative to $\beta$-actin. Statistical analysis was by unpaired Student's $t$-test. ${ }^{*} P=0.01$; NS indicates $P=0.13$.

implicated in the pathogenesis of chronic inflammatory diseases by genetic linkage and association studies (Lue et al. 2002, Gregersen \& Bucala 2003, Donn \& Ray 2004). Previously published work has suggested that, in addition to limiting the anti-inflammatory actions of GC, and thereby tending to exacerbate the intensity of inflammation, MIF is surprisingly upregulated by low concentrations of GC (Calandra et al. 1995). This latter mode of regulation was expected to result in locally acting, short feedback inhibition of the antiinflammatory actions of GG. Understanding the molecular mechanisms underlying such regulation is of prime importance.

GCs are potent anti-inflammatory agents, and act both to upregulate expression of anti-inflammatory cytokines, including IL-10 (Barnes 1998), but also to inhibit expression of most proinflammatory cytokines, including TNF- $\alpha$, and interleukin (IL)-1 (Barnes 1998, Neeck et al. 2002). Most proinflammatory cytokines lack consensus binding sites for the GR, and the activated GR inhibits such genes by interacting with DNA-bound NFKB or AP-1 transcription factors (Nissen \& Yamamoto 2000, Rogatsky et al. 2002). The MIF promoter is rich in $\mathrm{G}$ and $\mathrm{C}$ nucleotides, lacks a consensus GR binding site, but does contain a number of NFKB and AP-1 binding sites (Fig. 11). Therefore, it would appear to be paradoxical that such a gene would be upregulated by activated GR.

In order to understand how GC regulates MIF expression, we used a human $\mathrm{T}$ lymphoblast cell line, CEM C7A, and a human lung epithelial cell line, A549. Both cell lines express the GR, and we have previously shown that both cell lines are sensitive to $\mathrm{GG}$ by transfection of reporter genes (Soden et al. 2002). GG does not affect A549 cell death (Webster et al. 2002). Importantly, although very high GC concentrations of Dex (5000 nM) induce apoptosis in CEM C7A cells after a minimum incubation of $32 \mathrm{~h}$ (Brunet et al. 1998), the maximum time used in our experiments did not exceed 24 h.

In order to test the hypothesis that GC directly inhibits MIF promoter activity, a series of transient transfections into both the CEM C7A and A549 cells with MIF reporter gene constructs was performed. As we have previously described differential activity of MIF promoter haplotypes, we compared all eight theoretical promoter haplotypes in these studies (Donn et al. 2004). We initially examined the promoter activity of $-775 /+85$ MIF promoter constructs, with either the wild-type $\mathrm{G}$, or polymorphic $\mathrm{C}$ at position -173 . Both constructs were similarly inhibited in a dose-dependent manner by exposure to Dex in CEM C7A cells, but neither was significantly affected by Dex in A549 cells. The GC inhibition of MIF promoter activity in CEMC7A cells was specific, as we saw no such regulation of an SV40-luc reporter gene. Therefore, longer MIF promoter constructs, including not only the alleles at -173 but also the polymorphic repeat alleles at -794 , were similarly tested. Again we found that all the promoter haplotypes were repressed by Dex in CEM C7A cells but none of the constructs were significantly regulated in the A549 cells. Taken together, these data support the existence of previously unsuspected celltype-specific GC regulation of the MIF gene. As this effect was abolished by RU486, it can be assumed that Dex is acting through the GR.

There was no induction for $\mathrm{CATT}_{(5-7)}$-MIF$173 * \mathrm{G} / \mathrm{C}$ in CEM C7A cells with cAMP. This was unexpected, as cAMP has been shown to regulate the expression of rat MIF (Waeber et al. 1998), and there a potential binding site for cAMP responsive elementbinding protein (CREB) on the MIF promoter, as shown in Fig. 11. The absence of cAMP regulation in our study, as compared with that of Waeber et al., might be explained by the fact that they used the murine MIF promoter in primary rat pituitary cells, although the putative cAMP response element is conserved in human MIF (Fig. 11). This suggests that cAMP regulation might not be conserved across species or cell types.

In order to confirm that cpt cAMP used was capable of inducing a cAMP response, the experiment was repeated with a prolactin reporter gene. In contrast to the finding with the MIF reporter, the prolactin reporter was induced threefold (Fig. 3b). This was similar to our previously published data (Stevens et al. 2001). This indicated that the cAMP signalling pathway was intact in CEM C7A cells.

GC caused a marked suppression of MIF secretion from both cell lines, but the inhibition occurred at lower concentrations in A549 cells than in GEM G7A cells. 
(a)

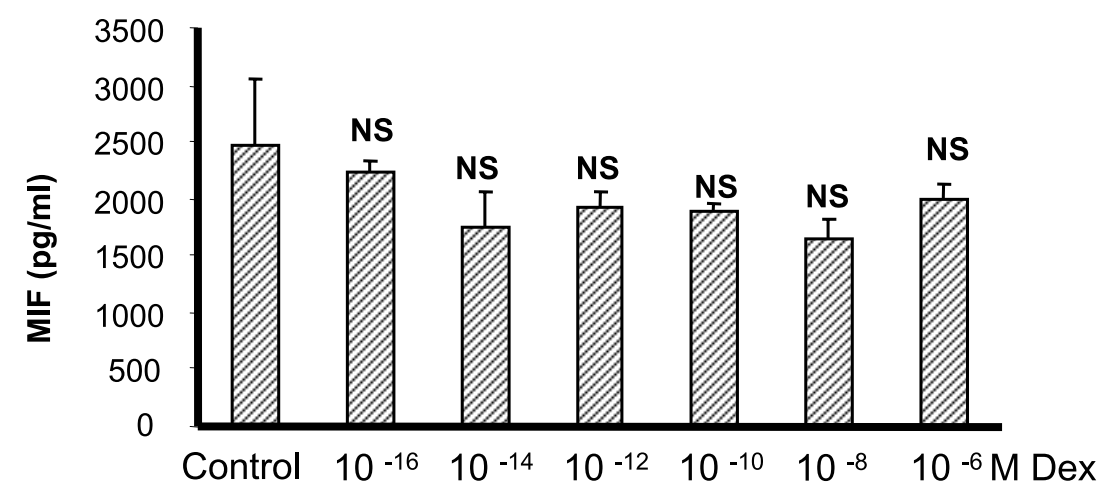

(b)

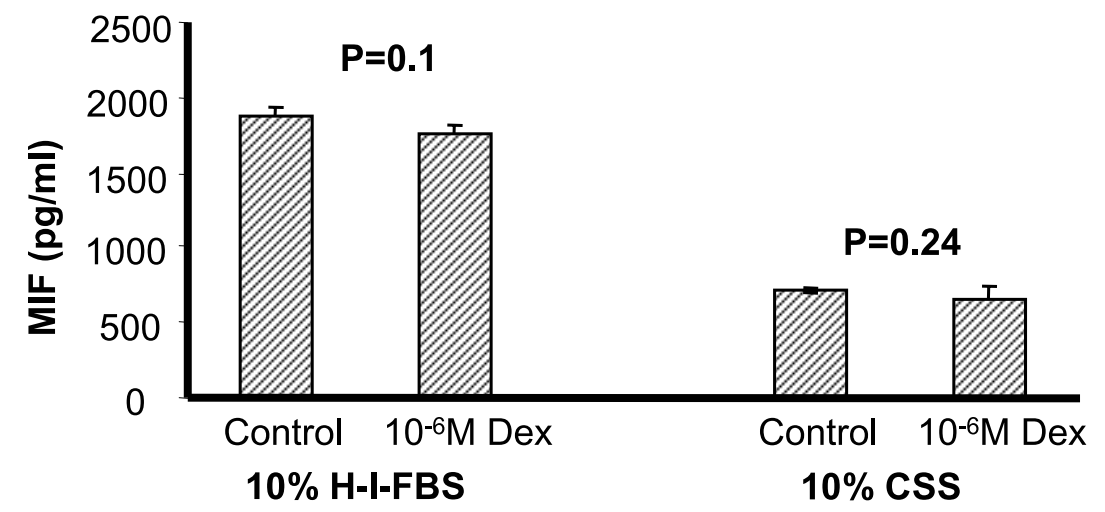

Figure 9 Glucocorticoid regulation of MIF secretion in RAW264.7 cells (a) RAW264.7 cells $\left(3 \times 10^{6}\right)$ were cultured in DMEM $+1 \%$ heat inactivated FBS $(\mathrm{H}-\mathrm{I}-\mathrm{FBS})$ and treated with vehicle or the indicated concentrations of dexamethasone. Cell conditioned medium was harvested after 24 hours incubation. MIF concentration was determined by ELISA. This experiment was performed in triplicate; mean and standard deviation are shown. NS indicates $P>0.05$. (b) RAW264.7 cells $\left(3 \times 10^{6}\right)$ were cultured in either DMEM $+10 \%$ heat inactivated FBS (H-I-FBS) or DMEM $+10 \%$ charcoal stripped fetal calf serum (CSS) and treated with vehicle or the indicated concentrations of dexamethasone. Analysis was as above. Exact significance values are shown.

This also accords with our earlier observations in the two cell lines, which showed that CEM G7A cells required higher concentrations of Dex to maximally activate a positive GG reporter gene (Soden et al. 2002). We have previously reported that inhibition of NFKB actions by GC occurs at lower concentrations of ligand than gene transactivation (Ray et al. 1999). Therefore, subnanomolar concentrations of Dex would be sufficient to inhibit MIF expression if the mechanism involved opposition of $\mathrm{NF \kappa B}$ or $\mathrm{AP}-1$ activity on the MIF promoter. Importantly, we found that conditions of serum deprivation $(0 \%$ or $1 \%$ FBS) prevented the inhibition of MIF secretion. This suggests an important mediating effect of serum components, as has been reported for expression of a number of proteins involved in protein translation (Meyuhas 2000).
If the inhibition of MIF secretion were dependent on the activated GR acting through NFKB on the MIF promoter, coordinate inhibition in MIF mRNA would be expected. However, although there was marked inhibition of MIF mRNA abundance in GEM C7A cells in response to Dex treatment, there was no effect was seen in A549 cells. This finding was unexpected, and suggested that in addition to GC having a potential anti-transcription or mRNA stability effect, seen in CEM C7A cells, there may also be an effect on MIF translation, protein stability or regulated secretion, explaining the results in A549 cells. Since the discrepancy between protein secretion and MIF mRNA abundance in A549 cells was so striking, we used two independent assays, Northern blot analysis and quantitative RT-PGR, to increase confidence in the results ${ }^{1011}$. 


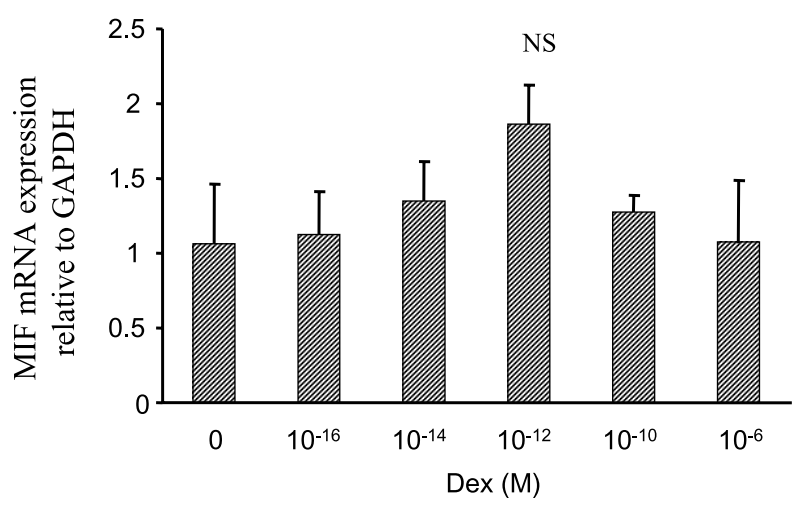

Figure 10 Glucocorticoid regulation of MIF mRNA in RAW264.7 cells. Cells were cultured in medium with $1 \%$ FBS and with either vehicle or dexamethasone (Dex) as indicated, and incubated for $24 \mathrm{~h}$. Total cell RNA was harvested, and cDNA was generated and analysed by quantitative RT-PCR for MIF expression relative to GAPDH. Statistical analysis was by ANOVA and Bonferroni $t$-test. NS indicates $P=0 \cdot 1$.

MIF secretion was suppressed in both the human cell lines studied. However, there was divergent regulation of MIF promoter. In the CEM C7A cells, there was marked inhibition of both the MIF promoter and also of
MIF mRNA, whereas no regulation was seen in A549 cells, despite inhibition of MIF secretion. Our results fit with the expected mode of GG regulation of proinflammatory cytokines, which is inhibition.

MIF secretion from rat monocytic cells (RAW264-7) is reported to be induced by low concentrations of GC (Calandra et al. 1995). Here, using two human cell lines, we were unable to find evidence to support such regulation. In addition, we have not been able to replicate the original finding in the same rat monocytic cell line, under a variety of serum concentrations.

It is unclear why our results diverge so markedly from those previously reported. The earlier reports used an immunoprecipitation-immunoblotting protocol that requires many more manipulations than the ELISA used in our studies, and the different antibodies used between the assays may differentially recognise post-translationally modified molecular species. The observation that the MIF promoter is differentially regulated by GC in two human cell lines that are both sensitive to GC action suggests the existence of additional important regulatory mechanisms or transcription factors that functionally interact with the GR. Such a complex mode of GC inhibition has not been described before for other proinflammatory cytokines.
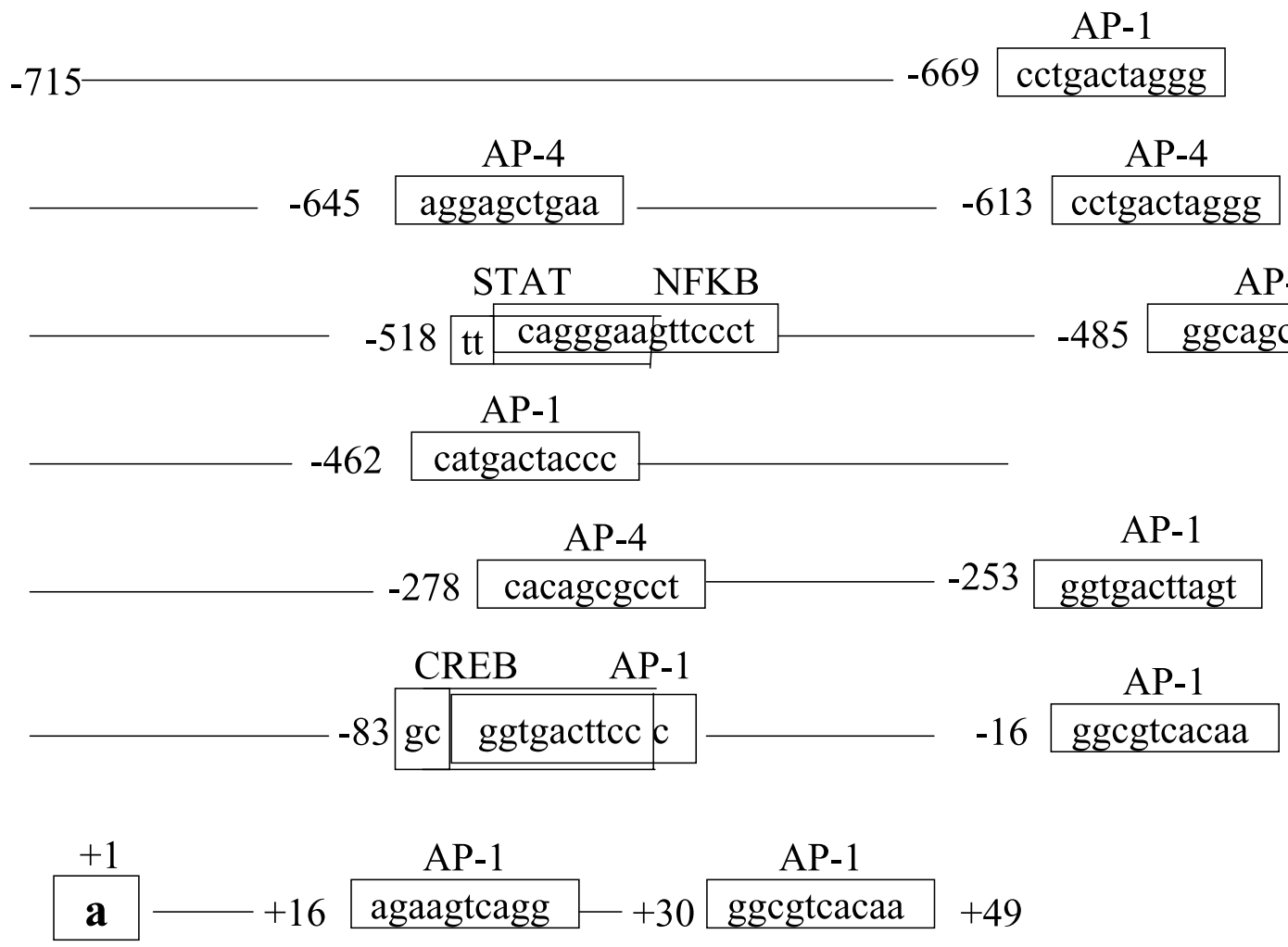

Figure 11 Potential transcription factor-binding sites in the wild-type human MIF sequence. Predicted binding sites for transcription factors in -832 CATT $(5-7)$-MIF-173G +85 (Embl ID: HSMIF accession no. L 19686.1), using AliBaba 2.1 (www.gene-regulation.com) and Matlnspector (www.genomatix.de/cgi-bin/matinspector/)software. 
Post-transcriptional regulation of translation is well described, affecting up to $30 \%$ of all mRNA species in cells (Meyuhas 2000). The failure of GC to regulate MIF in the RAW264.7 suggests further complexity in the cell-type-specific regulation of MIF expression. Understanding how GC regulates MIF expression in a cell-type-specific manner is of fundamental importance in revealing how and why GC act to suppress inflammation in a variable fashion between individuals and at different phases of disease.

\section{Acknowledgements}

Z A was supported by the Syrian government, D W R by a GlaxoSmithKline Fellowship, and R D by Arthritis Research Campaign. We thank Ian Laing for cortisol measurement by RIA.

\section{References}

Anonymous 1996 Heat inactivation - are you wasting your time? Art to Science (HyClone Newesletter) 15 1-5.

Baniahmad C, Muller M, Altschmied J \& Renkawitz R 1991 Co-operative binding of the glucocorticoid receptor DNA binding domain is one of at least two mechanisms for synergism. Fournal of Molecular Biology 222 155-165.

Barnes PJ 1998 Anti-inflammatory actions of glucocorticoids: molecular mechanisms. Clinical Science 94 557-572.

Barton A, Lamb R, Symmons D, Silman A, Thomson W, Worthington J \& Donn R 2003 Macrophage migration inhibitory factor (MIF) gene polymorphism is associated with susceptibility to but not severity of inflammatory polyarthritis. Genes and Immunity $\mathbf{4}$ 487-491.

Baugh JA, Chitnis S, Donnelly SC, Monteiro J, Lin X, Plant BJ, Wolfe F, Gregersen PK \& Bucala R 2002 A functional promoter polymorphism in the macrophage migration inhibitory factor (MIF) gene associated with disease severity in rheumatoid arthritis. Genes and Immunity 3 170-176.

Bloom BR \& Bennett B 1966 Mechanism of a reaction in vitro associated with delayed-type hypersensitivity. Science 153 80-82.

Boutillier AL, Sassone-Corsi P \& Loeffler JP 1991 The protooncogene c-fos is induced by corticotropin-releasing factor and stimulates proopiomelanocortin gene transcription in pituitary cells. Molecular Endocrinology 5 1301-1310.

Bozza M, Satoskar AR, Lin G, Lu B, Humbles AA, Gerard C \& David JR 1999 Targeted disruption of migration inhibitory factor gene reveals its critical role in sepsis. Fournal of Experimental Medicine $189341-346$.

Brunet CL, Gunby RH, Benson RS, Hickman JA, Watson AJ \& Brady G 1998 Commitment to cell death measured by loss of clonogenicity is separable from the appearance of apoptotic markers. Cell Death and Differentiation 5 107-115.

Calandra T, Bernhagen J, Metz CN, Spiegel LA, Bacher M, Donnelly T, Cerami A \& Bucala R 1995 MIF as a glucocorticoid-induced modulator of cytokine production. Nature 377 68-71.

David JR 1966 Delayed hypersensitivity in vitro: its mediation by cell-free substances formed by lymphoid cell-antigen interaction. PNAS 56 72-77.

De Benedetti F, Meazza C, Vivarelli M, Rossi F, Pistorio A, Lamb R, Lunt M, Thomson W, Ravelli A, Donn R \& Martini A 2003
Functional and prognostic relevance of the -173 polymorphism of the macrophage migration inhibitory factor gene in systemic-onset juvenile idiopathic arthritis. Arthritis and Rheumatism 48 1398-1407.

Diamond MI, Miner JN, Yoshinaga SK \& Yamamoto KR 1990 Transcription factor interactions: selectors of positive or negative regulation from a single DNA element. Science 249 1266-1272.

Donn R, Alourfi Z, De Benedetti F, Meazza C, Zeggini E, Lunt M, Stevens A, Shelley E, Lamb R, Ollier WE, Thomson W \& Ray D 2002 Mutation screening of the macrophage migration inhibitory factor gene: positive association of a functional polymorphism of macrophage migration inhibitory factor with juvenile idiopathic arthritis. Arthritis and Rheumatism 46 2402-2409.

Donn RP \& Ray DW 2004 Macrophage migration inhibitory factor (MIF): molecular, cellular and genetic aspects of a key neuroendocrine molecule. Fournal of Endocrinology 182 1-9.

Donn RP, Shelley E, Ollier WE \& Thomson W 2001 A novel 5 -flanking region polymorphism of macrophage migration inhibitory factor is associated with systemic-onset juvenile idiopathic arthritis. Arthritis and Rheumatism 44 1782-1785.

Donn RP, Alourfi Z, Zeggini E, Lamb R, Jury F, Lunt M, BPRG Study Group, Meazza C, De Benedetti F, Thomson W \& Ray D 2004 A functional promoter haplotype of macrophage migration inhibitory factor (MIF) is linked and associated with juvenile idiopathic arthritis. Arthritis and Rheumatism 50 1604-1610.

Fingerle-Rowson G, Koch P, Bikoff R, Lin X, Metz GN, Dhabhar FS, Meinhardt A \& Bucala R 2003 Regulation of macrophage migration inhibitory factor expression by glucocorticoids in vivo. American Fournal of Pathology 162 47-56.

Gregersen PK \& Bucala R 2003 Macrophage migration inhibitory factor, MIF alleles, and the genetics of inflammatory disorders: incorporating disease outcome into the definition of phenotype. Arthritis and Rheumatism 48 1171-1176.

Huynh TT, Ray DW, Brogan IJ, Stevens A, Davis JR, White A \& White A 2002 Failure of steroid regulation of the MMTV promoter in a small cell lung cancer cell line is caused by a DNA sequence flanking the glucocorticoid response element. Fournal of Endocrinology 172 295-302.

Leech M, Metz C, Santos L, Peng T, Holdsworth SR, Bucala R \& Morand EF 1998 Involvement of macrophage migration inhibitory factor in the evolution of rat adjuvant arthritis. Arthritis and Rheumatism 41 910-917.

Leech M, Lacey D, Xue JR, Santos L, Hutchinson P, Wolvetang E, David JR, Bucala R \& Morand EF 2003 Regulation of p53 by macrophage migration inhibitory factor in inflammatory arthritis. Arthritis and Rheumatism 48 1881-1889.

Lue H, Kleemann R, Calandra T, Roger T \& Bernhagen J 2002 Macrophage migration inhibitory factor (MIF): mechanisms of action and role in disease. Microbes and Infection 4 449-460.

Meyuhas O 2000 Synthesis of the translational apparatus is regulated at the translational level. European Fournal of Biochemistry $2676321-6330$.

Mikulowska A, Metz CN, Bucala R \& Holmdahl R 1997 Macrophage migration inhibitory factor is involved in the pathogenesis of collagen type II-induced arthritis in mice. Fournal of Immunology 158 5514-5517.

Muller M, Baniahmad C, Kaltschmidt C \& Renkawitz R 1991 Multiple domains of the glucocorticoid receptor involved in synergism with the CACGC box factor(s). Molecular Endocrinology $\mathbf{5}$ 1498-1503.

Neeck G, Renkawitz R \& Eggert M 2002 Molecular aspects of glucocorticoid hormone action in rheumatoid arthritis. Cytokines, Cellular and Molecular Therapy 7 61-69.

Nishihira J 1998 Novel pathophysiological aspects of macrophage migration inhibitory factor (review). International Fournal of Molecular Medicine 2 17-28.

Nissen RM \& Yamamoto KR 2000 The glucocorticoid receptor inhibits NFkappaB by interfering with serine-2 phosphorylation of 
the RNA polymerase II carboxy-terminal domain. Genes and Development 14 2314-2329.

Paralkar V \& Wistow G 1994 Cloning the human gene for macrophage migration inhibitory factor (MIF). Genomics 19 48-51.

Petrovsky N, Socha L, Silva D, Grossman AB, Metz C \& Bucala R 2003 Macrophage migration inhibitory factor exhibits a pronounced circadian rhythm relevant to its role as a glucocorticoid counter-regulator. Immunology and Cell Biology 81 137-143.

Ray DW, Suen CS, Brass A, Soden J \& White A 1999 Structure/function of the human glucocorticoid receptor: tyrosine 735 is important for transactivation. Molecular Endocrinology 13 1855-1863.

Rogatsky I, Luecke HF, Leitman DC \& Yamamoto KR 2002 Alternate surfaces of transcriptional coregulator GRIP1 function in different glucocorticoid receptor activation and repression contexts. PNAS 99 16701-16706.

Rogatsky I, Wang JC, Derynck MK, Nonaka DF, Khodabakhsh DB, Haqq CM, Darimont BD, Garabedian MJ \& Yamamoto KR 2003 Target-specific utilization of transcriptional regulatory surfaces by the glucocorticoid receptor. PNAS 100 13845-13850.

Santos L, Hall P, Metz C, Bucala R \& Morand EF 2001 Role of macrophage migration inhibitory factor (MIF) in murine antigeninduced arthritis: interaction with glucocorticoids. Clinical and Experimental Immunology 123 309-314.

Soden J, Stevens A \& Ray DW 2002 Genetic engineering of the glucocorticoid receptor by fusion with the herpes viral protein VP22 causes selective loss of transactivation. Fournal of Endocrinology 172 615-625.
Stevens A, Ray D, Alansari A, Hajeer A, Thomson W, Donn R, Ollier WE, Worthington J \& Davis JR 2001 Characterization of a prolactin gene polymorphism and its associations with systemic lupus erythematosus. Arthritis and Rheumatism 44 2358-2366.

Stevens A, Garside H, Berry A, Waters C, White A \& Ray DW 2003 Dissociation of SRCI and NCOR recruitment to the human glucocorticoid receptor by modification of the ligand-receptor interface. Molecular Endocrinology 17 845-849.

Stevens A, Ray DW, Zeggini E, John S, Richards HL, Griffiths CE \& Donn R 2004 Glucocorticoid sensitivity is determined by a specific glucocorticoid receptor haplotype. Fournal of Clinical Endocrinology and Metabolism 89 892-897.

Waeber G, Thompson N, Chautard T, Steinmann M, Nicod P, Pralong FP, Calandra T \& Gaillard RC 1998 Transcriptional activation of the macrophage migration-inhibitory factor gene by the corticotropin-releasing factor is mediated by the cyclic adenosine $3^{\prime}, 5^{\prime}$ - monophosphate responsive element-binding protein CREB in pituitary cells. Molecular Endocrinology 12 698-705.

Webster JC, Huber RM, Hanson RL, Collier PM, Haws TF, Mills JK, Burn TC \& Allegretto EA 2002 Dexamethasone and tumor necrosis factor-alpha act together to induce the cellular inhibitor of apoptosis-2 gene and prevent apoptosis in a variety of cell types. Endocrinology 143 3866-3874.

Received 19 November 2004

Accepted 13 December 2004 